\title{
ANGLE お勧めの本
}

\section{「ファジィモデリングとその応用」について}

\section{ANGLE 関西支部会計 御前 伸太}

はじめまして私は ANGLE 関西支部で会計を させてもらっている大阪府立大学経営工学科 $\mathrm{M} 1$ の御前伸太(みさきしんたと読みます)です。

今回，学会誌に載せてもらえるということで最 初は講座紹介をしようと思っていたのですが，す でに掲載されたとのことですので，代わりに大阪 府立大学の田中英夫教授の著書である「ファジィ モデリングとその応用」(朝倉書店)の紹介(宣 伝？）をしたいと思います。

まず，田中先生のプロフィールを紹介しますと 田中先生は 1938 年 9 月 28 日生で, '62 年神戸大学 工学部計測工学科卒業. 同年ダイキン工業株式会 社入社.' 69 年大阪市立大学大学院工学研究科博士 課程 (電気工学) 修了. 同年大阪府立大学工学部助 手, 講師助教授を経て, '87 年 7 月教授となり現在 に至っています。

次に，田中先生からの自己PRです。

現実問題に直面すると，現実問題に内包されて いる種々のあいまいさ，例えば（ｉ）認識のあいま いさ，(ii）現象に対する部分的無知，(iii）情報の 不完全性，(iv)評価の多様性，などがある。この ようなあいまいさに対処する方法論をファジイ理 論と呼んでいる，従ってこれは広範囲なものを含 んでおり，通常，理論と言われているものとかな り異なっている。ファジィ理論は現実のあいまい さを処理するためのものであり，その背景には常 に応用があると言える。

本書では，（i 市いまいな知識表現としてのフ アジィ集合，（ii）ファジィ集合による論理，（iii） ファジィ測度，（iv）可能性・必然性モデル，（v） 応用として有効なファジィモデル，などをファジ イ化の原理を中心にして述べている.

本書の特徴はファジィ化の原理を統一的に説明
し，なぜそのようなファジィモデリングを必要と するかを述べている，従って，大学院生の教科書 として適していると思う。

最後に，実際にこの本を読んだ人たちに感想を 聞いた結果を書いてみますと，いちばん多かった のは「難しかった」という意見で，次に多かった のは「奥が深い」で，続いて「おもしろかった」 でした、「難しかった」という意見が一番多かった のですが，私が実際に読んでみた感想は「難しい けれぞ奥が深い(つまり，奥が深いので難しい)」 で，他のファジィの本に較べて系統的にまとめて おり，初めてファジィを勉強する人でも，真剣に ファジィを勉強する気があれば，かなりの成果が 上がるはずです。ぜUあなたの心の友として一冊 どうですか？

ここで，紙面が少し余りましたので，おまけと して, 本学経営工学科第 3 講座の平成 3 年度 4 回 生の卒業論文のテーマの一部を載せておくことに します。それではまた紙面で会える日まで，さよ うなら。

・正規型可能性分布による可能性理論

・ファジィデータベースによるファジィ

if-then ルールの構築

・カオスファジィモデルの連想記憶への応用

・ファジィ非線形レギュレータの移動

ロボットへの応用

・ファジィ有限要素法の応用

・ファジィ・ニューラルネットワーク

・遺伝的アルゴリズムを用いたS A 法

（1991 年 10 月 5 日 受付） 